\title{
Pyranopyran-1,8-dione, an Active Compound from Vitices Fructus, Attenuates Cigarette-Smoke Induced Lung Inflammation in Mice
}

\author{
Gihyun Lee $^{\dagger}$ (D), Kyung-Hwa Jung ${ }^{\dagger}$, Eun Seok Ji and Hyunsu Bae * (D) \\ Department of Physiology, College of Korean Medicine, Kyung Hee University, 26 kyungheedae-ro, \\ dongdaemoon-gu, Seoul 02447, Korea; glee@khu.ac.kr (G.L.); jhkh242@naver.com (K.-H.J.); \\ ausomd@hanmail.net (E.S.J.) \\ * Correspondence: hbae@khu.ac.kr; Tel.: +822-961-9316 \\ † These authors contributed equally to this study.
}

Received: 28 June 2017; Accepted: 21 July 2017; Published: 24 July 2017

\begin{abstract}
Previously, we isolated and identified pyranopyran-1,8-dione (PPY) from Viticis Fructus, as a bioactive compound possessing anti-inflammatory properties. The present study was aimed to evaluate the preventive benefit of PPY on cigarette-smoke (CS)-induced lung inflammation. C57BL/6 mice were exposed to CS for 2 weeks while PPY was administrated by oral injection $2 \mathrm{~h}$ before CS exposure. To validate the anti-inflammatory effects of PPY, the numbers of immune cells in the bronchoalveolar lavage fluid were counted. Proinflammatory cytokines (Tumor necrosis factor- $\alpha$ : TNF- $\alpha$, IL-6) and keratinocyte chemokine (KC/CXCL1) were also measured. Histopathologic analysis and cellular profiles showed that inflammatory cell infiltrations were significantly decreased in peribronchial and perivascular area by PPY treatment. The alveolar destruction by CS was markedly ameliorated by PPY treatment. In addition, the TNF- $\alpha$, IL-6, and KC levels were declined in the PPY groups. These observations suggest that PPY has a preventive potential for lung inflammatory diseases.
\end{abstract}

Keywords: cigarette smoke; lung; inflammation; Viticis Fructus; phytochemical; pyranopyran-1; 8-dione

\section{Introduction}

During the last twenty years, new anti-inflammatory drugs are being discovered and developed as anti-cytokine agents with the massive expansion of the study on inflammatory response $[1,2]$. People, however, still long for cheaper and more effective alternative approaches to treat inflammation. Medicinal herbs have been used for treating inflammation related diseases, and they are often used to develop new medications [3-6]. It has been shown in a previous study that Fruit of Vitex trifolia subsp. litoralis Steenis, Viticis Fructus (VF), has anti-inflammatory properties, which occur via inhibition of the inflammatory cytokines and the mitogen-activated protein kinase (MAPK)-signaling pathway [5]. VF is widely used in China and Korea for the treatment of pain, cold, headache, migraine, sore eyes, myalgia, and gastrointestinal infections such as bacterial dysentery and diarrhea [7-9]. In one of our recent study, VF extract prevented the development of airway remodeling in asthma [10]. Therefore, we attempted to isolate the active compound from VF. After several rounds of activity-guided fractionations, pyranopyran-1,8-dione (PPY) was isolated (Figure 1) [11]. We previously reported that PPY inhibits inflammation in the ovalbumin-sensitized asthma mouse model [11]. Here, we used the CS-exposed mouse model for better understanding of the biomedical benefits of PPY, a natural chemical isolated from VF, on lung inflammation. In this study, we provide the evidence of PPY as a potent protective agent on lung inflammation. 


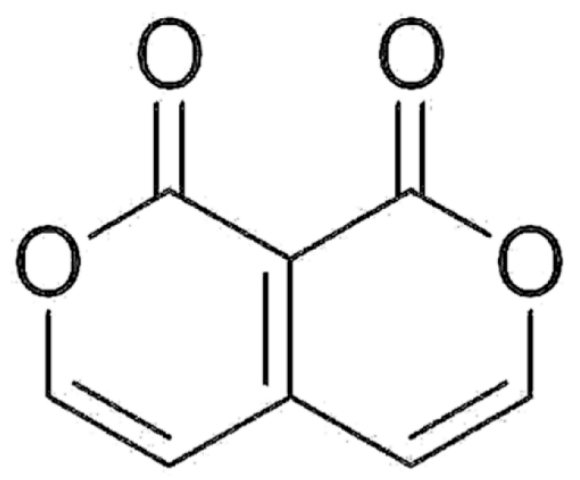

Figure 1. Structure of pyranopyran-1,8-dione.

\section{Results}

2.1. PPY Reduced Levels of Proinflammatory Cytokines and Chemokine KC in Bronchoalveolar Lavage (BAL) Fluid

To examine the anti-inflammatory activities of PPY, we evaluated level of proinflammatory cytokines (TNF- $\alpha$, IL-6) in Bronchoalveolar Lavage (BAL) fluid. The levels IL-6 and TNF- $\alpha$ were significantly raised by CS exposure. CS exposure followed our previous chronic obstructive pulmonary disease (COPD)-experiment protocol (Figure 2). However, the levels of TNF- $\alpha$ and IL-6 were reduced significantly in the roflumilast and PPY $(1,2$, and $10 \mathrm{mg} / \mathrm{kg})$ treatment. PPY treatment decreased the levels of TNF- $\alpha$ and IL-6 in a dose dependent manner (Figure 3A,B). The concentrations of $\mathrm{KC}$, neutrophil-chemoattractant chemokine, in BAL fluid were also measured with an ELISA. The expression of KC was increased in the CS group compared to the normal control (NC) group. Meanwhile, production of KC was declined in the roflumilast group and PPY $(1,2$, and $10 \mathrm{mg} / \mathrm{kg})$ groups compared to the CS group (Figure 3C).

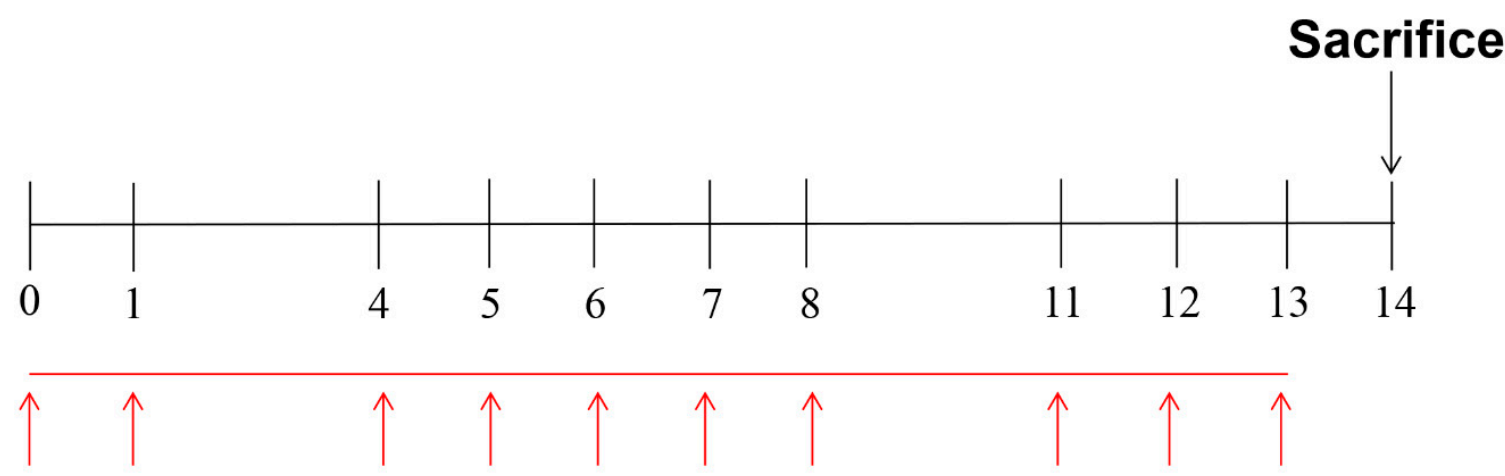

Expose to air or smoke (6 cigarettes/day)

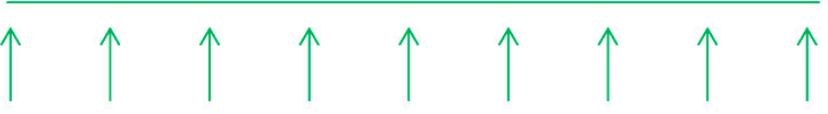

Therapeutic ( $2 \mathrm{hr}$ before smoke exposure)

Figure 2. Schematic diagram of the experimental protocol Balb/c mice were exposed to cigarette smoke (CS, 6 cigarettes/day on day $0,1,4,5,6,7,8,11,12$, and 13). For therapeutic study, vehicle, roflumilast $(5 \mathrm{mg} / \mathrm{kg})$, or PPY $(1,2$ and $10 \mathrm{mg} / \mathrm{kg})$ were administered $2 \mathrm{~h}$ before CS exposure from day 5 to 13. The mice were killed on day 14 . 
A

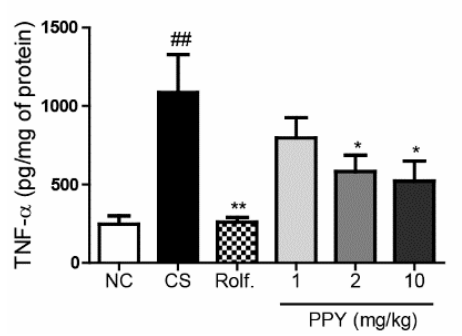

B

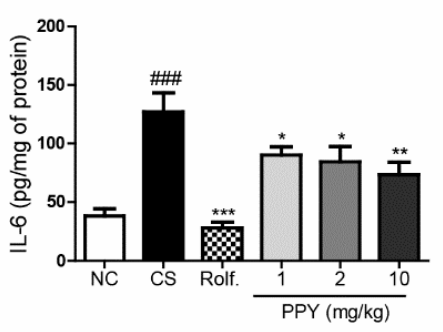

C

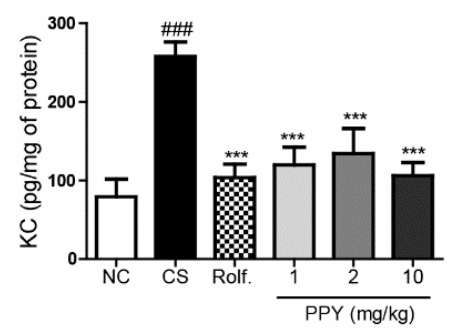

Figure 3. The effect of PPY on proinflammatory cytokine (TNF- $\alpha$, IL-6) and KC levels in BAL fluid. Pro-inflammatory cytokine (TNF- $\alpha$, IL-6) and CXCL-1 (KC) productions were measured using ELISA in the BAL fluid. (A) TNF- $\alpha$; (B) IL-6 and (C) KC. Data are shown as mean \pm S.E.M. Statistical analyses were conducted by one-way analysis of variance (ANOVA) followed by Newman-Keuls Multiple Comparison test (\#\#\# $p<0.001$, \#\# $p<0.01$ vs. NC, ${ }^{* * *} p<0.001,{ }^{* *} p<0.01,{ }^{*} p<0.05$ vs. CS; $n=5-6$ ).

\subsection{PPY Inhibited the Recruitment of Inflammatory Cells into BAL Fluid}

We next evaluated immune cell infiltrations in peribronchial airway. CS exposure significantly increased the numbers of lymphocytes, macrophages, neutrophils, and total cells in BAL fluid. However, oral administration of PPY $(1,2$ and $10 \mathrm{mg} / \mathrm{kg})$ or roflumilast markedly diminished the number of infiltrated immune cells including lymphocytes, macrophages, and neutrophils into lung tissue. The effect of PPY was comparable to that of roflumilast (Figure 4).

A

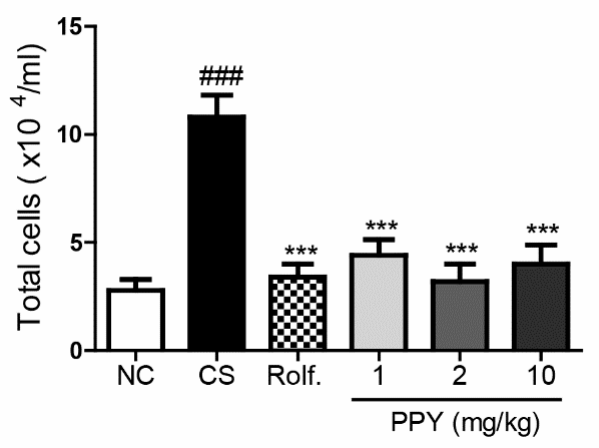

C

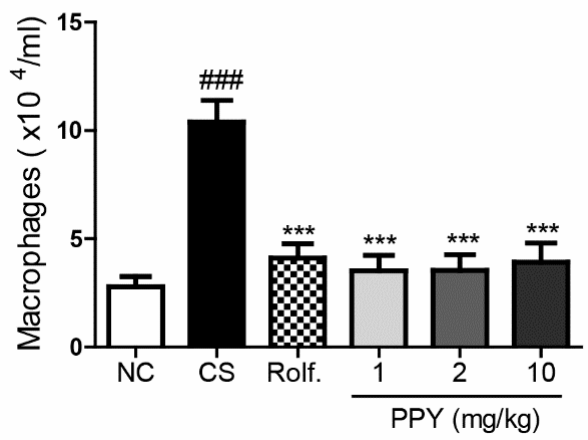

B

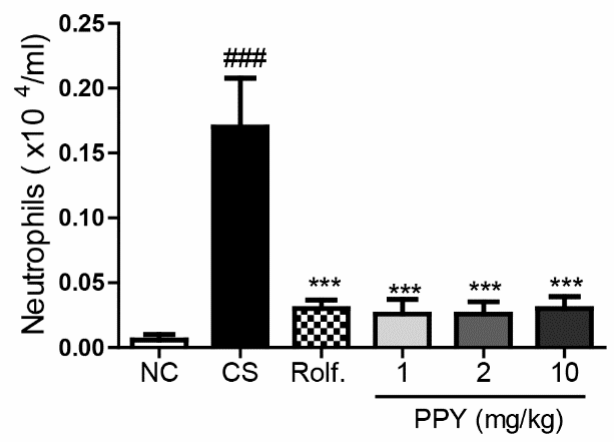

D

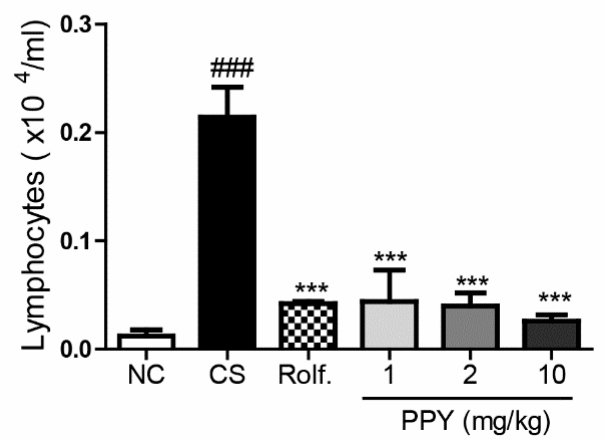

Figure 4. The effect of PPY on inflammatory cells in BAL fluid profiles. The numbers of cells in BAL fluid were counted using a hemocytometer, and differential cell counts were performed on slides prepared by cytocentrifugation at $250 \mathrm{rpm}$ for $3 \mathrm{~min}$ followed by Diff-Quick staining. (A) Total cell number; (B) Macrophage count; (C) Neutrophil count; (D) Lymphocyte count. Data are shown as mean \pm S.E.M. Statistical analyses were conducted by one-way ANOVA followed by Newman-Keuls Multiple Comparison test (\#\#\# $p<0.001$ vs. NC, ${ }^{* * *} p<0.001$ vs. CS; $n=5-6$ ). 


\subsection{PPY Decreased the Morphological Change in Lung Tissue}

To confirm the anti-inflammatory effects of PPY in histological feature, H\&E staining was performed on the lung tissues (Figure 5A). Peribronchial region of the H\&E stained tissued were ramdomly evaluated by patholosits. The histologic data showed that CS exposure caused peribronchial inflammation, whereas PPY or roflumilast treatment blocked it. The inflammatory index was significantly reduced in both the PPY group and the roflumilast group when compared to the CS group (Figure 5B). We also assessed the mean alveolar airspace to quantify the changes of airspace enlargement in the peribronchial regions. In the CS exposed mice, some alveoli were destroyed, resulting in enlarged air spaces indicating emphysematous changes. PPY- or roflumilast-treatment ameliorated the alveolar damages based on this quantitative assessment (Figure 5C).

A

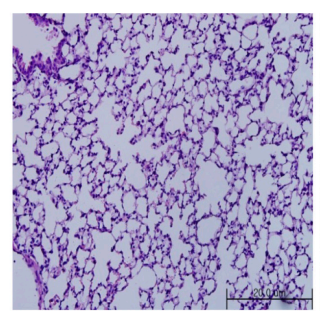

NC

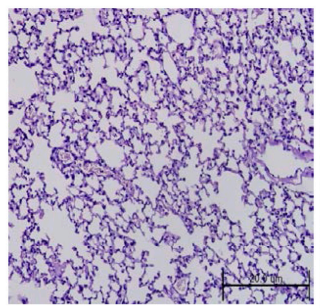

CS+PPY

$(1 \mathrm{mg} / \mathrm{kg})$

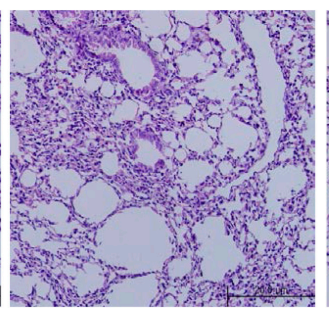

CS

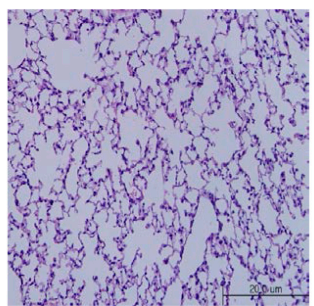

CS+Rofl.
B
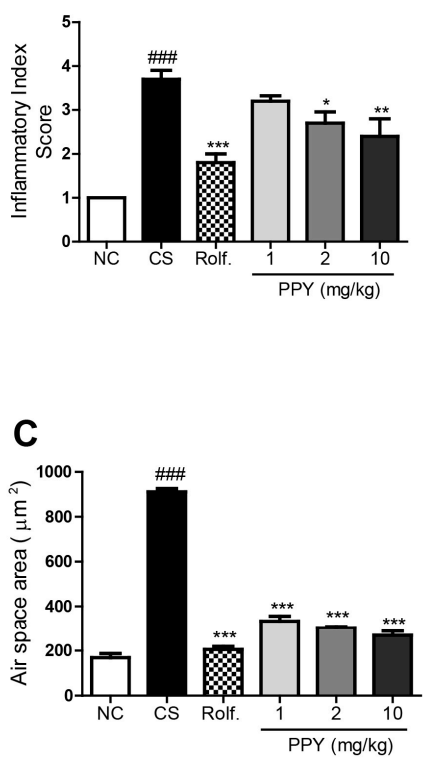

Figure 5. The effect of PPY on peribronchial inflammation and airspace enlargement in lung tissue (A) The right lower lobes of lung tissues were stained with H\&E. to assess peribronchail inflammation (magnification 200×) as described in Materials and Methods; (B) Corresponding histopathological scores for lung inflammation. Peribronchial inflammation was evaluated on a subjective score 0 to 5 on blinded, randomized sections by three independent pathologists. All sections were scored from 0 to 5 according to the following criteria: $0=$ normal; $1=$ very mild; 2 = mild; 3 = moderate; 4 = marked; 5 = severe inflammation; (C) A morphometrical analysis for mean alveolar airspace was assessed using Image Pro-Plus 5.1 software as described in Materials and Methods. Data are shown as mean \pm S.E.M. Statistical analyses were conducted by one-way ANOVA followed by Newman-Keuls Multiple Comparison test (\#\#\# $p<0.001$ vs. NC, ${ }^{* * *} p<0.001,{ }^{* *} p<0.01,{ }^{*} p<0.05$ vs. CS; $n=5-6$ ).

\subsection{Effect of PPY on Goblet Cell Hyperplasia}

Periodic acid-Schiff (PAS) staining is used to evaluate goblet cell hyperplasia. We stained lung tissues with PAS to examine the anti-mucosal effect of PPY (Figure 6A). PAS stained cells were located around the peribronchial regions in the CS group, as expected. While, PPY treatment markedly decreased the percent of PAS-positive goblet cells around the bronchial airway (Figure 6B). 
A

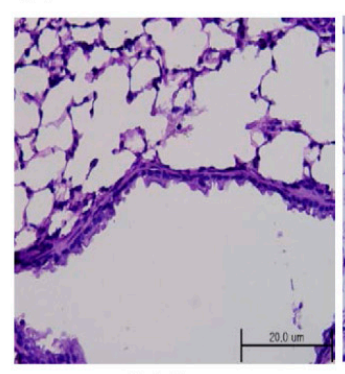

NC

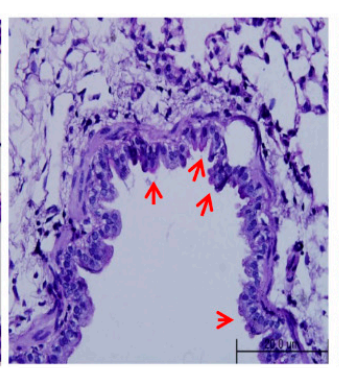

CS

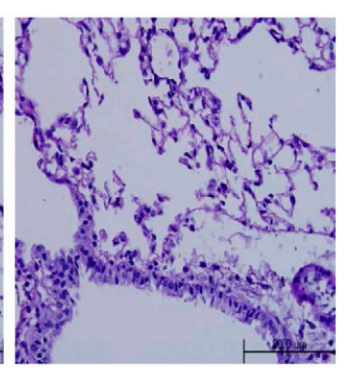

CS+Rofl.
B

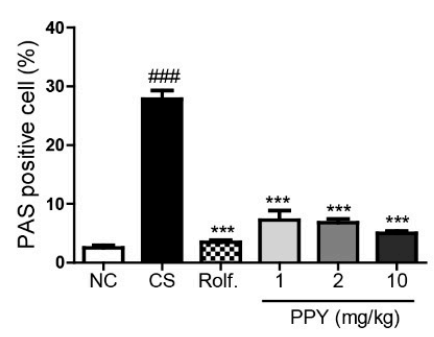

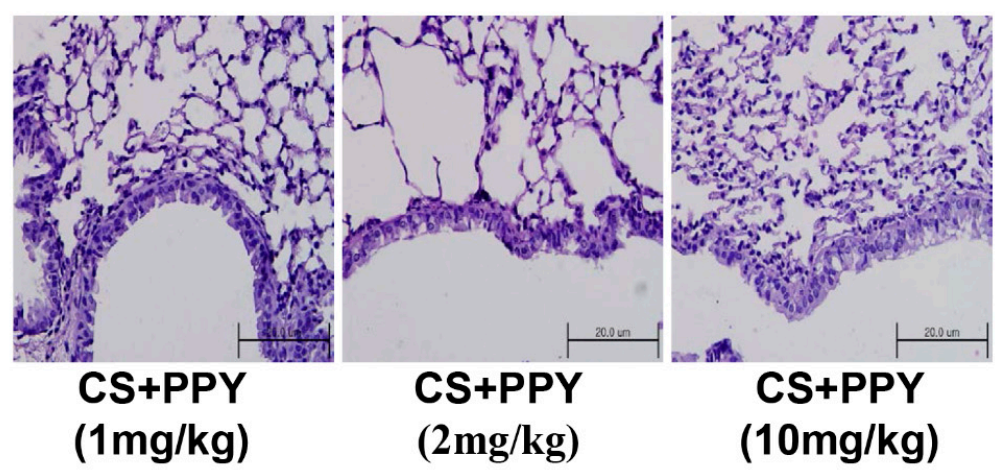

Figure 6. The effect of PPY on the histopathologic changes in lung. The right lower lobes of lung tissue were dissected and stained with periodic acid-Schiff (PAS). (A) The arrow indicates the PAS-positive cells (magnification $400 \times$ ); (B) PAS-positive mucosal goblet cells around the bronchial airway were counted and are depicted as the percentage of goblet cells, as described in Materials and Methods. Data are shown as mean \pm SEM. Statistical analyses were conducted by one-way ANOVA followed by Newman-Keuls Multiple Comparison test (\#\#\# $p<0.001$ vs. NC, ${ }^{* * *} p<0.001$ vs. CS; $n=5-6$ ).

\section{Discussion}

Pathophysiological characters of COPD include inflammation, goblet cell hyperplasia, remodeling of the airways, and alveolar destruction [12]. Cigarette smoking is the most common risk factor in the development of COPD [13]. CS contains a large number of oxidants, and several adverse effects of CS may appear as the result of oxidative damage to critical biological substances and nuclear factor- $\mathrm{KB}$ (NF- $\mathrm{KB}$ ) [14]. In addition, $\mathrm{CS}$ attacks lung tissue and activates lung-resident cells, including dendritic cells (DCs), alveolar macrophages, and epithelial cells, which release several inflammatory mediators that are capable of assembling inflammatory cells into lungs. Subsequently, this leads to a release of proinflammatory cytokines (TNF- $\alpha$, IL-6) and chemotactic factors, antibacterial proteins, proteases, growth factors, and anti-inflammatory cytokines [15-18]. One of the main roles of alveolar macrophages is the secretion of chemotactic factors and this role is significantly increased by CS exposure. The enhanced release of chemotactic factors results in increased lung neutrophil infiltration, which is thought to be a key event in the development of COPD [19]. Furthermore, CXC chemokines such as IL-8, GRO- $\alpha$, and KC play important roles in lung inflammation though they also have a chemotactic activity for alveolar macrophage [20,21].

Many previous studies have demonstrated that neutrophils, one of the assembled inflammatory cells induced by CS, increase in the sputum and lung tissue of patients with COPD and cause the recruitment of several types of inflammatory cells in the lung [18]. These immune cells secret proteases including matrix metalloproteinase-9, which leads to emphysema [22]. The morphological changes were also accompanied by an increase in lung lymphocytes, macrophages, macrophage-derived metalloproteases, neutrophils, neutrophil elastase, oxidants, IL-6, and TNF- $\alpha$, all of which have been demonstrated to play significant roles in the pathogenesis of emphysema [23]. TNF- $\alpha$ is known as the 
activator of other proinflammatory cytokines including IL-6 and IL-8 [24]. TNF- $\alpha$ also induced NF- $\mathrm{kB}$ activation [25]. Also, IL-6 is a target in COPD as it triggers endothelial cell malfunction, leading to enlarged alveolar air spaces [26].

Though many medications are used for the treatment of COPD, side effects appear in several classes of drugs including steroids. For example, roflumilast is a widely used medication for COPD treatment. Nonetheless, roflumilast has dose-limiting adverse effects including weight loss, dizziness, insomnia, diarrhea, vomiting, headache, and nausea [27-29]. Thus, it is prudent that safer and more efficacious therapeutics for COPD are developed [30].

Natural herbs are successfully employed as anti-inflammatory agents with low adverse effects [30-32]. Therefore, they are considered as harmless alternatives to conventional medicines. Numerous research laboratories are currently using phytomedicines to control inflammatory responses. In the last ten years, more than 52 natural compounds, including chrysin were validated [33,34]. PPY is a new compound isolated from VF. Our previous study demonstrated that PPY blocked NF-kB activation in lung epithelial cells, resulting in a suppressed asthmatic response in ovalbumin-induced asthma. In addition, the pharmacological effect of PPY has been shown to be mediated by blocking activation of the NF- $\mathrm{KB}$ and the ERK1/2-signaling pathways and inhibiting the accumulation of eosinophil into the airway, and decreasing the levels of IL-4, IL-5, and IL-13 in BAL fluid. Based on the study, PPY has shown the potential as a novel therapeutic agent for allergic asthma [11]. The NF-KB pathway is an important drug target with regard to inflammation and metabolic dysfunction [35,36].

In this research, the effect of PPY on lung inflammation was examined in a CS-exposed mouse model. This model is preferred for research aiming to evaluate the degree of suppression of lung inflammation since it is caused by the equal factor and produces similar pathophysiological alterations including emphysema and airway remodeling with human COPD [37]. As a result, CS exposure raised the functional and structural changes, typical phenotypes of COPD in our model. The changes include increased levels of KC, IL-6, and TNF- $\alpha$; goblet cell hyperplasia; airway remodeling; air space enlargement; and increased numbers of immune cells in the alveoli and airways. PPY treatment, on the other hand, inhibited these changes induced by CS exposure. PPY significantly decreased production of KC, IL-6, and TNF- $\alpha$ and suppressed immune cell infiltrations in the lung tissue. Reactive oxygen species (ROS) and toll-like receptors (TLRs) signals can also mediate airway inflammation. Zuo et al. have shown that increased level of pulmonary TNF- $\alpha$ can induce excessive ROS formation and targeting TLR cascade can be option for amelioration of airway inflammation [38,39]. Although effects of PPY on ROS and TLRs signaling are not unfold in this study, it is needed a detailed molecular mechanism of PPY in airway inflammation in further study. Besides, the role of IL-17 in pulmonary inflammation should not be underestimated. IL-17 signaling contributes for pulmonary immunopathology [40,41]. We tried to measure level of IL-17a in BAL fluid, however failed detection. The effect of PPY on IL-17 production in lung inflammation also should be evaluated in the future.

Histopathologic analysis confirmed that PPY treatment inhibits accumulation of inflammatory cells (especially neutrophils) and goblet cell hyperplasia throughout the peribronchial airway. Moreover, it is demonstrated that PPY treatment can protect from the structural changes induced by CS exposure through airspace quantitative assessment. In the study, however, we did not investigate the detailed mechanisms involved for these therapeutic effects. Experiments for validating the curative effects of PPY and conventional drug (ex. roflumilast) co-treatment are necessary to confirm the therapeutic benefits of PPY on COPD.

In conclusion, our data provide evidence that PPY has remarkable therapeutic benefits for CS-induced lung inflammation. Thus, we suggest PPY as a promising candidate for the treatment of lung inflammation. Further studies are required to elucidate detailed mechanisms and to develop the application to use PPY as a drug. 


\section{Materials and Methods}

\subsection{Reagent}

PPY was isolated in the Institute for Korea Traditional Medical Industry (Gyeongsan, Korea). There, $3 \mathrm{~kg}$ of VF was extracted with $\mathrm{MeOH}(10 \mathrm{~L} \times 5)$ by percolation for $24 \mathrm{~h}$. To get a MeOH educt $(100 \mathrm{~g})$, the $\mathrm{MeOH}$ was evaporated in vacuo, then suspended in $1 \mathrm{~L}$ of $\mathrm{H}_{2} \mathrm{O}$, and separated with $n$-BuOH $(1 \mathrm{~L} \times 3)$, EtOAc $(1 \mathrm{~L} \times 5)$, and $n$-hexane $(1 \mathrm{~L} \times 5)$. The EtOAc partition $(17 \mathrm{~g})$ was divided by silica gel using gradient mixtures of $\mathrm{MeOH}$ in $\mathrm{CHCl}_{3}(0 \rightarrow 50 \%$, and washed with $\mathrm{MeOH} 100 \%, 5 \mathrm{~L}$ each), affording PPY (0.0078\% w/w, $235 \mathrm{mg})$. Roflumilast was dissolved in dimethylsulfoxide and then diluted with PBS.

\subsection{Animal}

The Kyung Hee University Animal Care and Use Committee approved the study protocol. The approval number is KHUASP (SE)-12-015 (10/10/2015). All experiments were conducted on 6 to 7 weeks old Balb/c female mice bought from Charles River Korea (Seungnam, Republic of Korea). They were kept under pathogen-free conditions with an air-conditioning, food provided ad libitum, and $12 \mathrm{~h}$ light/dark cycle.

\subsection{Exposure to CS and Animal Treatment}

CS exposure followed our previous COPD-experiment protocol (Figure 2) [42]. In brief, mice were divided randomly into six groups ( $n=6 \sim 7 /$ group). NC group: mice were exposed to only fresh air in the same duration of exposure to CS; CS group: mice were exposed to cigarette smoke from 3R4F reference cigarette (University of Kentucky, Lexington, KY, USA) for two weeks with six cigarettes per day, on day $0,1,4,5,6,7,8,11,12,13$; roflumilast group: roflumilast ( $5 \mathrm{mg} / \mathrm{kg}$ ) was injected orally $2 \mathrm{~h}$ before CS exposure; PPY (1, 2 and $10 \mathrm{mg} / \mathrm{kg})$ group: PPY (1, 2 and $10 \mathrm{mg} / \mathrm{kg})$ was injected orally $2 \mathrm{~h}$ before CS exposure. All animals were sacrificed $24 \mathrm{~h}$ later after the last CS exposure. The experiments were performed two times independently.

\subsection{Analysis of Inflammatory Cell Profiles in BAL Fluid}

One $\mathrm{ml}$ of PBS was slowly infused into the lungs and withdrawn three consecutive times (final volume $2-2.5 \mathrm{~mL}$ ). BAL fluid was then centrifuged and the supernatants were stored at $-80{ }^{\circ} \mathrm{C}$ ultralow freezer until further use. The total viable cells were counted using a hemacytometer. Approximately Five hundred cells were counted. Differential cell counts with trypan blue exclusion method were performed on slides prepared by cytospin preparations (Sandon, Waltham, MA, USA) and Diff-Quick staining.

\subsection{ELISA Analysis of IL-6, TNF- $\alpha$, and CXCL1/KC}

Total protein content in BAL fluid was measured using the BCA kit (Pierce Biotechnology Inc., Rockford, IL, USA) according to the manufacturer's instructions. The levels of TNF- $\alpha$, IL-6, and CXCL1/KC in the BAL fluid were measured with a commercial enzyme immunoassay kit (Becton Dickinson Bioscience, San Jose, CA, USA for TNF- $\alpha$ and IL-6; R\&D systems, Minneapolis, MN, USA for Mouse CXCL1/KC) following the manufacturers' protocols.

\subsection{Immunohistochemistry of Lungs}

Lungs were fixed by $4 \%$ paraformaldehyde infusion. Sliced lungs in $4 \mu \mathrm{m}$ were stained with $\mathrm{H} \& \mathrm{E}$ sequentially for histological examination. Randomly selected five sections were examined using Image Pro-Plus 5.1software (Media Cybernetics, Inc., Silver Spring, MD, USA). To observe hyperplasia of goblet cells in the bronchial airway, some sliced tissues were stained with periodic acid Schiff (PAS). 


\subsection{Statistical Analysis}

All values are presented as mean \pm SEM. The statistical significance between study groups were assessed by one-way ANOVA followed by Newman-Keuls multiple comparison test using Prism 5.01 software (GraphPad Software Inc., San Diego, CA, USA). $p<0.05$ was considered to be statistically significant.

Acknowledgments: This study was supported by a grant of the Basic Science Research Program administered by the National Research Foundation, which is funded by the Ministry of Science, Information \& Communication Technology (ICT) and Future Planning, Republic of Korea (NRF-2017R1A2B3009574).

Author Contributions: Hyunsu Bae conceived and designed the experiments; Kyung-Hwa Jung and Eun Seok Ji performed the experiments; Gihyun Lee and Kyung-Hwa Jung analyzed the data and wrote the paper; all authors refined and agreed on the final manuscript.

Conflicts of Interest: The authors declare no conflict interest.

\section{References}

1. Rainsford, K.D. Anti-inflammatory drugs in the 21st century. Subcell. Biochem. 2007, 42, 3-27. [PubMed]

2. D'Acquisto, F.; Maione, F.; Pederzoli-Ribeil, M. From il-15 to il-33: The never-ending list of new players in inflammation. Is it time to forget the humble aspirin and move ahead? Biochem. Pharmacol. 2010, 79, 525-534. [CrossRef] [PubMed]

3. Chung, H.S.; Kang, M.; Cho, C.; Parvez, S.; Park, C.H.; Kim, D.; Oh, J.; Kim, H.; Shin, M.; Hong, M.; et al. Inhibition of nitric oxide and tumor necrosis factor- $\alpha$ by moutan cortex in activated mouse peritoneal macrophages. Biol. Pharm. Bull. 2007, 30, 912-916. [CrossRef] [PubMed]

4. Sohn, S.H.; Ko, E.; Oh, B.G.; Kim, S.H.; Kim, Y.; Shin, M.; Hong, M.; Bae, H. Inhibition effects of vitex rotundifolia on inflammatory gene expression in a549 human epithelial cells. Ann. Allergy Asthma Immunol. 2009, 103, 152-159. [CrossRef]

5. Sohn, S.H.; Ko, E.; Oh, B.G.; Kim, J.; Choi, E.; Kim, S.H.; Kim, Y.; Shin, M.; Hong, M.; Bae, H. Global gene analysis of erigeron canadensis-treated TNF- $\alpha-$, IL-4- and IL-1 $\beta$-stimulated A549 human epithelial cells. Ann. Nutr. Metab. 2009, 54, 227-235. [CrossRef] [PubMed]

6. Sohn, S.H.; Ko, E.; Kim, Y.; Shin, M.; Hong, M.; Bae, H. Genomewide expression profile of forsythia suspensa on lipopolysaccaride-induced activation in microglial cells. Mol. Cell Toxicol. 2008, 4, 113-123.

7. Hu, Y.; Hou, T.T.; Xin, H.L.; Zhang, Q.Y.; Zheng, H.C.; Rahman, K.; Qin, L.P. Estrogen-like activity of volatile components from Vitex rotundifolia L. Indian J. Med. Res. 2007, 126, 68-72. [PubMed]

8. Okuyama, E.; Fujimori, S.; Yamazaki, M.; Deyama, T. Pharmacologically active components of viticis fructus (Vitex rotundifolia). Ii. The components having analgesic effects. Chem. Pharm. Bull. (Tokyo) 1998, 46, 655-662. [CrossRef] [PubMed]

9. Shin, T.Y.; Kim, S.H.; Lim, J.P.; Suh, E.S.; Jeong, H.J.; Kim, B.D.; Park, E.J;; Hwang, W.J.; Rye, D.G.; Baek, S.H.; et al. Effect of Vitex rotundifolia on immediate-type allergic reaction. J. Ethnopharmacol. 2000, 72, 443-450. [CrossRef]

10. Bao, M.J.; Shen, J.; Jia, Y.L.; Li, F.F.; Ma, W.J.; Shen, H.J.; Shen, L.L.; Lin, X.X.; Zhang, L.H.; Dong, X.W.; et al. Apple polyphenol protects against cigarette smoke-induced acute lung injury. Nutrition 2012, 29, 235-243. [CrossRef] [PubMed]

11. Lee, H.; Han, A.R.; Kim, Y.; Choi, S.H.; Ko, E.; Lee, N.Y.; Jeong, J.H.; Kim, S.H.; Bae, H. A new compound, 1H,8H-Pyrano[3,4-C]Pyran-1,8-Dione, suppresses airway epithelial cell inflammatory responses in a murine model of asthma. Int. J. Immunopathol. Pharmacol. 2009, 22, 591-603. [CrossRef] [PubMed]

12. Qiu, C.; Li, Y.; Li, M.; Liu, X.; McSharry, C.; Xu, D. Anti-interleukin-33 inhibits cigarette smoke-induced lung inflammation in mice. Immunology 2013, 138, 76-82. [CrossRef] [PubMed]

13. Siafakas, N.M.; Tzortzaki, E.G. Few smokers develop copd. Why? Respir. Med. 2002, 96, 615-624. [CrossRef] [PubMed]

14. Cavarra, E.; Bartalesi, B.; Lucattelli, M.; Fineschi, S.; Lunghi, B.; Gambelli, F.; Ortiz, L.A.; Martorana, P.A.; Lungarella, G. Effects of cigarette smoke in mice with different levels of $\alpha(1)$-proteinase inhibitor and sensitivity to oxidants. Am. J. Respir. Crit. Care Med. 2001, 164, 886-890. [CrossRef] [PubMed] 
15. Mills, P.R.; Davies, R.J.; Devalia, J.L. Airway epithelial cells, cytokines, and pollutants. Am. J. Respir. Crit. Care Med. 1999, 160, S38-S43. [CrossRef] [PubMed]

16. Di Stefano, A.; Capelli, A.; Lusuardi, M.; Balbo, P.; Vecchio, C.; Maestrelli, P.; Mapp, C.E.; Fabbri, L.M.; Donner, C.F.; Saetta, M. Severity of airflow limitation is associated with severity of airway inflammation in smokers. Am. J. Respir. Crit. Care Med. 1998, 158, 1277-1285. [CrossRef] [PubMed]

17. Mio, T.; Romberger, D.J.; Thompson, A.B.; Robbins, R.A.; Heires, A.; Rennard, S.I. Cigarette smoke induces interleukin-8 release from human bronchial epithelial cells. Am. J. Respir. Crit. Care Med. 1997, 155, 1770-1776. [CrossRef] [PubMed]

18. Witherden, I.R.; Vanden Bon, E.J.; Goldstraw, P.; Ratcliffe, C.; Pastorino, U.; Tetley, T.D. Primary human alveolar type II epithelial cell chemokine release: Effects of cigarette smoke and neutrophil elastase. Am. J. Respir. Cell Mol. Biol. 2004, 30, 500-509. [CrossRef] [PubMed]

19. Murugan, V.; Peak, M.J. Signal transduction pathways linking the actication of alveolar macrophages with the recruitment of neutrophils to lungs in chronic obstructive pulmonary disease. Exp. Lung Res. 2009, 35, 439-485. [CrossRef] [PubMed]

20. Goodman, R.B.; Foster, D.C.; Mathewes, S.L.; Osborn, S.G.; Kuijper, J.L.; Forstrom, J.W.; Martin, T.R. Molecular cloning of porcine alveolar macrophage-derived neutrophil chemotactic factors I and II; identification of porcine IL-8 and another intercrine- $\alpha$ protein. Biochemistry 1992, 31, 10483-10490. [CrossRef] [PubMed]

21. Huvenne, W.; Perez-Novo, C.A.; Derycke, L.; De Ruyck, N.; Krysko, O.; Maes, T.; Pauwels, N.; Robays, L.; Bracke, K.R.; Joos, G.; et al. Different regulation of cigarette smoke induced inflammation in upper versus lower airways. Respir. Res. 2010, 11, 100. [CrossRef] [PubMed]

22. Ichinose, M. Differences of inflammatory mechanisms in asthma and copd. Allergol. Int. 2009, 58, 307-313. [CrossRef] [PubMed]

23. Churg, A.; Wright, J.L. Animal models of cigarette smoke-induced chronic obstructive lung disease. Contrib. Microbiol. 2007, 14, 113-125. [PubMed]

24. Drost, E.M.; MacNee, W. Potential role of il-8, platelet-activating factor and TNF- $\alpha$ in the sequestration of neutrophils in the lung: Effects on neutrophil deformability, adhesion receptor expression, and chemotaxis. Eur. J. Immunol. 2002, 32, 393-403. [CrossRef]

25. Rozema, E.; Atanasov, A.G.; Fakhrudin, N.; Singhuber, J.; Namduang, U.; Heiss, E.H.; Reznicek, G.; Huck, C.W.; Bonn, G.K.; Dirsch, V.M.; et al. Selected extracts of chinese herbal medicines: Their effect on NF-кB, PPAR $\alpha$ and PPAR $\gamma$ and the respective bioactive compounds. Evid. Based Complement. Altern. Med. 2012, 2012, 983023. [CrossRef] [PubMed]

26. Barnes, P.J.; Celli, B.R. Systemic manifestations and comorbidities of copd. Eur. Respir. J. 2009, 33, 1165-1185. [CrossRef] [PubMed]

27. Calverley, P.M.; Rabe, K.F.; Goehring, U.M.; Kristiansen, S.; Fabbri, L.M.; Martinez, F.J. M2-124 and M2-125 study groups. Roflumilast in symptomatic chronic obstructive pulmonary disease: Two randomised clinical trials. Lancet 2009, 374, 685-694. [CrossRef]

28. Rabe, K.F.; Bateman, E.D.; O’Donnell, D.; Witte, S.; Bredenbroker, D.; Bethke, T.D. Roflumilast-An oral anti-inflammatory treatment for chronic obstructive pulmonary disease: A randomised controlled trial. Lancet 2005, 366, 563-571. [CrossRef]

29. Page, C.P.; Spina, D. Phosphodiesterase inhibitors in the treatment of inflammatory diseases. Handb. Exp. Pharmacol. 2011, 391-414.

30. Blanc, P.D.; Trupin, L.; Earnest, G.; Katz, P.P.; Yelin, E.H.; Eisner, M.D. Alternative therapies among adults with a reported diagnosis of asthma or rhinosinusitis: Data from a population-based survey. Chest 2001, 120, 1461-1467. [CrossRef] [PubMed]

31. Clark, C.E.; Arnold, E.; Lasserson, T.J.; Wu, T. Herbal interventions for chronic asthma in adults and children: A systematic review and meta-analysis. Prim. Care Respir. J. 2010, 19, 307-314. [CrossRef] [PubMed]

32. George, J.; Ioannides-Demos, L.L.; Santamaria, N.M.; Kong, D.C.; Stewart, K. Use of complementary and alternative medicines by patients with chronic obstructive pulmonary disease. Med. J. Aust. 2004, 181, 248-251. [PubMed]

33. Maione, F.; Russo, R.; Khan, H.; Mascolo, N. Medicinal plants with anti-inflammatory activities. Nat. Prod. Res. 2016, 30, 1343-1352. [CrossRef] [PubMed] 
34. Rauf, A.; Khan, R.; Raza, M.; Khan, H.; Pervez, S.; de Feo, V.; Maione, F.; Mascolo, N. Suppression of inflammatory response by chrysin, a flavone isolated from potentilla evestita th. Wolf. In silico predictive study on its mechanistic effect. Fitoterapia 2015, 103, 129-135. [CrossRef] [PubMed]

35. Ghosh, S.; Hayden, M.S. New regulators of NF-kB in inflammation. Nat. Rev. Immunol. 2008, 8, 837-848. [CrossRef] [PubMed]

36. Bierhaus, A.; Schiekofer, S.; Schwaninger, M.; Andrassy, M.; Humpert, P.M.; Chen, J.; Hong, M.; Luther, T.; Henle, T.; Kloting, I.; et al. Diabetes-associated sustained activation of the transcription factor nuclear factor-kb. Diabetes 2001, 50, 2792-2808. [CrossRef] [PubMed]

37. Wright, J.L.; Cosio, M.; Churg, A. Animal models of chronic obstructive pulmonary disease. Am. J. Physiol. Lung Cell. Mol. Physiol. 2008, 295, L1-L15. [CrossRef] [PubMed]

38. Zuo, L.; Hallman, A.H.; Roberts, W.J.; Wagner, P.D.; Hogan, M.C. Superoxide release from contracting skeletal muscle in pulmonary TNF- $\alpha$ overexpression mice. Am. J. Physiol. Regul. Integr. Comp. Physiol. 2014, 306, R75-R81. [CrossRef] [PubMed]

39. Zuo, L.; Lucas, K.; Fortuna, C.A.; Chuang, C.C.; Best, T.M. Molecular regulation of toll-like receptors in asthma and copd. Front. Physiol. 2015, 6, 312. [CrossRef] [PubMed]

40. Lore, N.I.; Bragonzi, A.; Cigana, C. The IL-17A/IL-17RA axis in pulmonary defence and immunopathology. Cytokine Growth Factor Rev. 2016, 30, 19-27. [CrossRef] [PubMed]

41. Willis, C.R.; Siegel, L.; Leith, A.; Mohn, D.; Escobar, S.; Wannberg, S.; Misura, K.; Rickel, E.; Rottman, J.B.; Comeau, M.R.; et al. IL-17RA signaling in airway inflammation and bronchial hyperreactivity in allergic asthma. Am. J. Respir. Cell Mol. Biol. 2015, 53, 810-821. [CrossRef] [PubMed]

42. Jung, K.H.; Haam, K.K.; Park, S.; Kim, Y.; Lee, S.R.; Lee, G.; Kim, M.; Hong, M.; Shin, M.; Jung, S.; et al. The standardized herbal formula, PM014, ameliorated cigarette smoke-induced lung inflammation in a murine model of chronic obstructive pulmonary disease. BMC Complement. Altern. Med. 2013, 13, 219. [CrossRef] [PubMed]

(C) 2017 by the authors. Licensee MDPI, Basel, Switzerland. This article is an open access article distributed under the terms and conditions of the Creative Commons Attribution (CC BY) license (http:/ / creativecommons.org/licenses/by/4.0/). 